\title{
Intraspecific variation in phenology offers resilience to climate change for Eriophorum vaginatum $^{1}$
}

\author{
Thomas C. Parker, Steven L. Unger, Michael L. Moody, Jianwu Tang, and Ned Fetcher
}

\begin{abstract}
The phenology of Arctic plants is an important determinant of the pattern of carbon uptake and may be highly sensitive to continued rapid climate change. Eriophorum vaginatum L. (Cyperaceae) has a disproportionate influence over ecosystem processes in moist acidic tundra, but it is unclear whether its growth and phenology will remain competitive in the future. We investigated whether northern tundra ecotypes of E. vaginatum could extend their growing season in response to direct warming and transplanting into southern ecosystems. At the same time, we examined whether southern ecotypes could adjust their growth patterns in order to thrive further north, should they disperse quickly enough. Detailed phenology measurements across three reciprocal transplant gardens over a 2-year period showed that some northern ecotypes were capable of growing for longer when conditions were favourable, but their biomass and growing season length was still shorter than those of the southern ecotype. Southern ecotypes retained large leaf length when transplanted north and mirrored the growing season length better than the others, mainly owing to immediate green-up after snowmelt. All ecotypes retained the same senescence timing, regardless of environment, indicating a strong genetic control. Eriophorum vaginatum may remain competitive in a warming world if southern ecotypes can migrate north.
\end{abstract}

Key words: phenology, tundra, Eriophorum vaginatum, ecotype, climate change.

Résumé : La phénologie des plantes arctiques constitue un déterminant important du modèle d'absorption du carbone et elle peut être très sensible à un changement climatique rapide et continu. Eriophorum vaginatum L. (Cyperaceae) a une influence démesurée sur les processus de l'écosystème dans la toundra acide humide, mais on ne sait pas si sa croissance et sa phénologie resteront compétitives à l'avenir. Les auteurs ont voulu savoir si les écotypes d'E. vaginatum de la toundra du nord pouvaient prolonger leur saison de croissance en réponse au réchauffement direct et à la transplantation dans les écosystèmes du sud. En parallèle, ils se sont demandé si les écotypes du sud pouvaient ajuster leur type de croissance afin de bien pousser plus au nord, s'ils se dispersent assez rapidement. Des mesures détaillées de la phénologie dans trois jardins de transplantations réciproques et sur 2 ans ont montré que certains écotypes du nord étaient capables de croître plus longtemps

Received 2 October 2020. Accepted 27 January 2021.

T.C. Parker. Biological and Environmental Sciences, School of Natural Sciences, University of Stirling, Stirling FK9 4LA, UK.

S.L. Unger. Florida International University, 11200 SW 8th Street, Miami, FL 33199, USA.

M.L. Moody. Department of Biological Sciences, University of Texas at El Paso, El Paso, TX 79902, USA.

J. Tang. The Ecosystems Center, Marine Biological Laboratory, Woods Hole, MA 02543, USA.

N. Fetcher. Institute for Environmental Science and Sustainability, Wilkes University, Wilkes-Barre, PA 18766, USA.

Corresponding author: Thomas C. Parker (e-mail: t.c.parker@stir.ac.uk).

${ }^{1}$ This paper is part of a Special Issue entitled: Impacts of climate change on tundra ecosystems: Three decades of results from the International Tundra Experiment (ITEX).

(C) 2021 The Author(s). This work is licensed under a Creative Attribution 4.0 International License (CC BY 4.0)

http://creativecommons.org/licenses/by/4.0/deed.en_GB, which permits unrestricted use, distribution, and reproduction in any medium, provided the original author(s) and source are credited. 
lorsque les conditions étaient favorables, mais leur biomasse et la durée de leur saison de croissance étaient toujours plus courtes que celles de l'écotype du sud. Les écotypes du sud conservaient une grande longueur de feuilles lorsqu'ils étaient transplantés au nord et reflétaient mieux la durée de la saison de croissance que les autres, principalement en raison du verdissement immédiat après la fonte des neiges. Tous les écotypes conservaient le même moment de sénescence, indépendamment de l'environnement, ce qui indique un fort contrôle génétique. Eriophorum vaginatum peut rester compétitif dans un monde en réchauffement si les écotypes du sud peuvent migrer vers le nord. [Traduit par la Rédaction]

Mots-clés : phénologie, toundra, Eriophorum vaginatum, écotype, changement climatique.

\section{Introduction}

The Arctic is warming at twice the global mean, resulting in profound changes in not only temperature but also precipitation and growing season length (Mudryk et al. 2019). Biological processes in the Arctic are closely tuned to environmental cues and as such are showing signals of change in response to a changing climate (Post et al. 2009). This is important because living organisms hold critical control over biogeochemical, energy, and hydrological fluxes, with huge potential to further exacerbate climate change (Wookey et al. 2009). Plant communities across the Arctic have shown particularly striking changes in response to warming as they grow taller (Bjorkman et al. 2018), increase in cover, and undergo shifts in dominance, with mosses often in decline and deciduous shrubs in ascendance (Elmendorf et al. 2012b). Natural observations of change are supported by experimental evidence showing that there are clear winners and losers in the plant community as the climate continues to change (Elmendorf et al. 2012a).

The direct effects of warming on Arctic plant community composition and growth have been well studied through a circumpolar network of open-top chamber (OTC) experiments (Elmendorf et al. 2012a). These generally show that plant growth increases with warming and that deciduous shrubs increase in dominance, but also that responses are mediated by site conditions such as local climate and soil moisture (Elmendorf et al. 2012a). Wider observation networks are detecting "greening" signals with increases in height and cover at the plot level (Bjorkman et al. 2018) and increases in the normalized difference vegetation index (NDVI) at satellite levels (Epstein et al. 2012). Observations of the expansion of deciduous shrub cover are consistent with these trends (Myers-Smith et al. 2011). One of the key findings is that certain groups in the community, such as mosses, decrease in cover as the community responds to warming, while the response of other groups, such as sedges, is mixed (Elmendorf et al. 2012a). It is important to understand how all constituents of the plant community will change in the future because they all contribute significantly to ecosystem processes such as primary productivity, reflectance, and phenology, among others (Myers-Smith et al. 2019).

Climate change in the Arctic is multifaceted and will affect aspects of plant performance in different ways (Post et al. 2009; Box et al. 2019). For example, summer growing seasons are extending in the Arctic owing to reductions in snow cover duration (SCD) (Box et al. 2019). Model projections indicate that SCD over much of the Arctic will decline by about $10 \%-30 \%$ by the end of this century as a consequence of delayed onset of snow cover as well as earlier snowmelt (Brown et al. 2017). The projected decrease in SCD implies that the potential growing season should lengthen, as found by Park et al. (2016), who used NDVI to analyze changes in growing season length in boreal and Arctic vegetation. Broadly speaking, plant phenology in the Arctic has been shown to be sensitive to abiotic conditions (Prevéy et al. 2017; Assmann et al. 2019). At the beginning of the growing season, earlier snowmelt should result in earlier green-up, as abundant sunshine and the disappearance 
of snow produces good growing conditions. Many studies have documented the importance of snowmelt timing for controlling the phenology of Arctic plants with earlier snowmelt, which usually results in earlier onset of growth (Høye et al. 2007; Bjorkman et al. 2015; Khorsand Rosa et al. 2015; Semenchuk et al. 2016; May et al. 2020). Once the growing season is underway, it is less clear whether higher mean temperatures will affect plant phenology, in part because of interactions with snowmelt timing (Oberbauer et al. 2013). Geographical patterns in phenology further complicate the response of Arctic plants to climate change. Across the Arctic, phenology of plants from more northern sites have exhibited greater sensitivity to warming temperatures than plants from sites at more southern latitudes (Prevéy et al. 2017).

Increasing temperatures in autumn (Box et al. 2019) may offer an opportunity to plant communities to grow for longer, but it is difficult to forecast the effect of mid- and lateseason growing conditions on phenology in the autumn. If autumn temperatures increase, it is not clear that Arctic plants will respond by extending their growing season (Parker et al. 2017). Many species start to turn yellow in August, when temperatures are still warm (Shaver and Laundre 1997). This may be because, in the Arctic, harsh winter conditions can appear suddenly, which could result in the loss of valuable resources through frost damage to live aboveground biomass that has not fully senesced. Some functional groups, notably some graminoids, may be able to delay senescence in response to warming conditions, while other functional groups may have fixed leaf life spans that are correlated with average growing season lengths (Oberbauer et al. 2013). Manipulation of the timing of green-up by removing snow or adding it with snow fences has shown that the length of phenological stages such as growth, flowering, or seed setting remained invariant even though the dates of start-up varied greatly (Khorsand Rosa et al. 2015; Semenchuk et al. 2016). Semenchuk et al. (2016) concluded that a range of herbaceous and shrub species in their study are periodic, meaning that the duration of phenological periods is genetically fixed. By extension, therefore, even if the end-of-season environment is suitable for continued growth, tundra plants may senesce early if their green-up was early.

While many studies have focused on variation at the species and community levels of organization, few studies have looked at intraspecific variation in the phenology of tundra plants. Since most Arctic plants have widespread distributions, local adaptations are likely to be important for many species (Linhart and Grant 1996). Local adaptation is widespread in plant populations, especially those consisting of many individuals covering a wide geographic range (Leimu and Fischer 2008; Hereford et al. 2009). Wagner and Simons (2009) reported differences between the phenology of the Arctic and alpine populations of the annual Koenigia islandica, with the Arctic population flowering earlier than the alpine population. Bjorkman et al. (2017) reported that southern populations of the Arctic plants Oxyria digyna and Papaver radicatum were slower to leaf out and to initiate senescence than northern (local) populations. Likewise, Parker et al. (2017) showed that senescence of Eriophorum vaginatum grown in a common garden occurs later for populations from the southern portions of a latitudinal gradient in the Alaskan Arctic. Although growth rates were the same, the southern populations were able to accumulate more biomass because of the longer growing season (Parker et al. 2017). Thus, it is important to base models of phenology on not only a generalized phenotype but also the variation within species across their range where local dynamics may vary, although the assemblage remains the same.

Many Arctic plant species are distributed along the latitudinal gradient from the Low to the High Arctic, which provides ample scope for locally adapted populations or ecotypes. Strong adaptation to local climates may render Arctic plants vulnerable to rapid climate change in their locales if they are not able to respond quickly enough (McGraw et al. 2015). The degree of phenotypic plasticity of ecotypes of Arctic plants may determine their 
potential to take advantage of, or survive, warmer conditions. Eriophorum vaginatum is a foundational species of moist acidic tundra, meaning that it strongly dictates the system's physical structure as well as its process rates (Chapin and Shaver 1985). Eriophorum vaginatum demonstrates clear ecotypic differentiation in phenotypes (Shaver et al. 1986; Fetcher and Shaver 1990) and gene expression (Mohl et al. 2020) across its South-North distribution in Alaska, which reflects a wide range of growing season conditions. McGraw et al. (2015) showed that the optimal environment for tussock survival and tiller population growth in E. vaginatum had shifted northwards, meaning that this important species may suffer from "adaptational lag" and thus may not keep pace with current rates of climate change. To address this lag in performance, local populations may need to be supplemented by gene flow from the south (McGraw et al. 2015). Performance of the northern ecotypes of E. vaginatum is less flexible than that of the southern ecotypes in both net ecosystem exchange (Curasi et al. 2019) and leaf growth (Fetcher and Shaver 1990). But as previously stated, changes in growing season length offer plants new opportunities to grow for longer and remain competitive in their environment.

Here we investigate the role of genetic background and environmental conditions as they affect the phenology of E. vaginatum growing in a reciprocal transplant experiment in northern Alaska, USA. We used this system to ask the following questions:

1. Can the phenology of E. vaginatum ecotypes match growing conditions when transplanted into warmer ecosystems with longer growing seasons?

2. Do southern populations retain their growth patterns when transplanted north?

3. Do local ecotypes increase growth and growing season length when experimentally warmed in situ?

4. Does E. vaginatum exhibit a fixed periodicity in its phenology, that is, if it starts growing early will it senesce early?

\section{Materials and methods}

\section{Site description and experimental design}

Eriophorum vaginatum L. (Cyperaceae) is a tussock-forming sedge that has a strong influence on tundra microclimate and carbon cycling potential (Chapin et al. 1979). It covers large areas of northeastern Siberia (Walker et al. 2005) and is also found in wetlands and moorlands throughout the circumpolar region (Wein 1973). In Alaska, full-sized adult tussocks can consist of 300-600 live tillers (Fetcher and Shaver 1982). Tussocks can live for well over 100 years (Mark et al. 1985) and can vary widely in size (Shaver et al. 1986).

Three common gardens of reciprocally transplanted tussocks of E. vaginatum were established at Sagwon (SG; $69.42^{\circ} \mathrm{N}, 148.72^{\circ} \mathrm{W}$, elev. $300 \mathrm{~m}$ ), Toolik Lake (TL; $68.63^{\circ} \mathrm{N}$, $149.36^{\circ} \mathrm{W}$, elev. $760 \mathrm{~m}$ ) and Coldfoot (CF; $67.26^{\circ} \mathrm{N}, 150.17^{\circ} \mathrm{W}$, elev. $\left.331 \mathrm{~m}\right)$ along the Dalton Highway in Alaska, USA. CF is $\sim 4^{\circ} \mathrm{C}$ warmer than the other sites during the summer months of June and July, and mean temperature stays above freezing for 2 more months during spring and autumn, resulting in more thawing degree days (Supplementary Figs. S1 and S2 ${ }^{2}$ ). Although SG is further north, it is at a lower elevation than TL, resulting in similar overall temperature regimes (Supplementary Figs. S1 and S2 ${ }^{2}$ ). Tussocks of E. vaginatum dominate all three sites, with deciduous shrubs (Betula nana L., Salix spp., and Vaccinium uliginosum L.) and evergreen shrubs (Vaccinium vitis-idaea L., Rhododendron tomentosum Harmaja), mosses, and lichens growing in between the tussocks. The northern

\footnotetext{
${ }^{2}$ Supplementary material is available with the article at https://doi.org/10.1139/as-2020-0039.
} 
ecotypes of E. vaginatum are found at Sagwon, which is on the northern edge of moist acidic tundra and may not have been glaciated during the Pleistocene, and at Toolik Lake, which is in the moist acidic tundra near the Brooks Range and was most recently glaciated in the Late Wisconsinan ( 20 000 years BP) (Hamilton 2003; Kaufman and Manley 2004; Walker et al. 2005; Kaufman et al. 2011). One of the southern ecotypes is found at Coldfoot, in a muskeg with encroaching trees (Picea mariana (Mill.) B.S.P.) that were not present in 1982 when previous common gardens were established (Shaver et al. 1986). Coldfoot was glaciated during the Early Wisconsinan ( 70 000- 40 000 years BP), but probably not during the Late Wisconsinan (Kaufman and Manley 2004; Kaufman et al. 2011). The three sites were likely colonized by E. vaginatum at different times and therefore were differentiating as ecotypes for different amounts of time; nonetheless, they have all had at least 20000 years to potentially develop traits that reflect their home environments.

In August 2014, mature tussocks were transplanted between the three sites, with tussocks from each home site transplanted into another area within their home site as controls according to methods specified in Bennington et al. (2012) and Schedlbauer et al. (2018). Briefly, a serrated knife was used to sever the rhizomes from roots and soil at a tussock's base and remove it from the tundra. Tussocks were then placed in the vacant positions at the common garden where local tussocks had been removed. This method has a high success rate because of E. vaginatum's deciduous rooting habit; although roots are severed during transplanting, new roots grow in each subsequent year, restoring full root function (Bennington et al. 2012). Tussocks were planted in clusters of three, $\sim 0.5 \mathrm{~m}$ apart from each other. Clusters were paired at SG and TL, where one cluster of each pair was passively warmed using OTCs (Schedlbauer et al. 2018). Ten pairs of clusters of the three populations were arranged in an approximately $25 \mathrm{~m} \times 30 \mathrm{~m}$ grid. OTCs were placed on the selected clusters from 11 July to 28 August 2015, from 2 June to 28 August 2016, and from 30 May to 26 August 2017, causing a mean hourly air temperature increase of 1.16 and $1.04{ }^{\circ} \mathrm{C}$ at Sagwon in 2016 and 2017, respectively. At Toolik Lake, the respective temperature increases were 0.60 and $1.01^{\circ} \mathrm{C}$. At CF, where there was no warming treatment, clusters were arranged as singletons in a smaller grid $(25 \mathrm{~m} \times 15 \mathrm{~m})$. At each site, 10 nontransplanted tussocks were identified next to the transplant garden in order to assess the effect of transplanting on the measured response variables.

\section{Leaf measurements}

Through the growing seasons of 2016 and 2017 (early June to mid-September), leaf growth and senescence were monitored on transplanted tussocks. Growing season air temperatures at each transplant garden during the measurement years were representative of the typical climatic conditions of each site (Supplementary Table S1 ${ }^{2}$ ). A tiller from one tussock of each cluster was tagged and monitored according to Shaver and Laundre (1997) and Parker et al. (2017). A small zip tie was secured around the base of the tiller so as to include all leaves with any visible green portions while excluding any previously senesced leaves from previous growth. The total leaf length and the length of the green portions were measured to the nearest $5 \mathrm{~mm}$ approximately once a week for each leaf in a tiller, from oldest to youngest.

\section{Tiller phenology data processing}

The senesced portions of leaves were fragile and sometimes broke off; since this occurred after leaves had reached their full length, the total length was corrected to match the last measurement of the unbroken leaf. Where lengths of single leaves were missing for a time point owing to human error, they were replaced with the mean of the previous and following time points. Only leaves that were growing during the season of measurement 
Fig. 1. Example of double logistic model (eq. 1) fit to the growth pattern of a tiller over a growing season and metrics that can be calculated from this curve (in red, left panel) and fit to two other example datasets (in black, right panel).

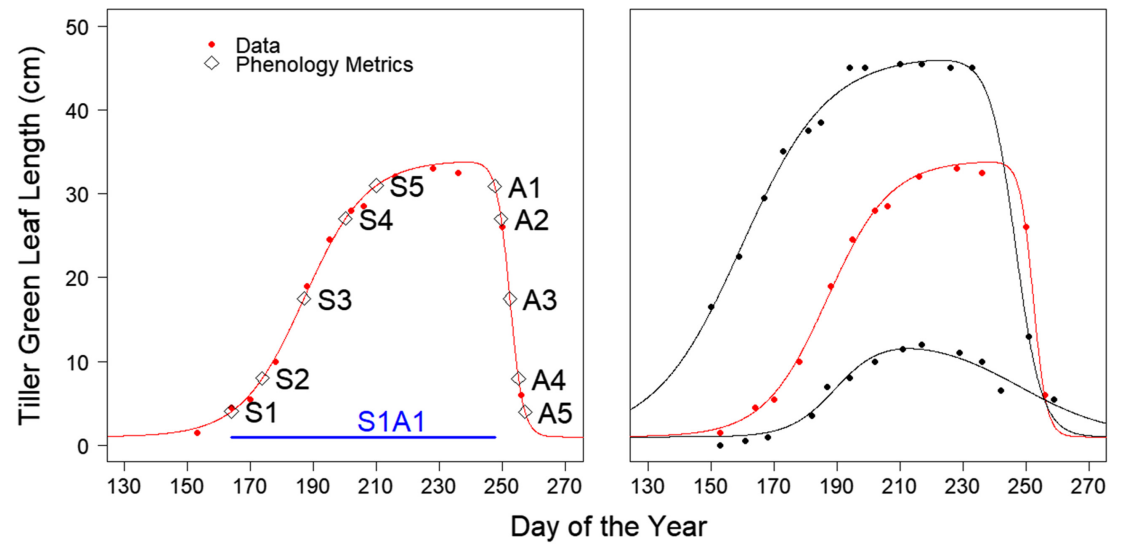

were measured, thereby excluding leaves that were grown in the previous year and were senescing as well as leaves that had been initiated for the next year but were not elongating. A double logistic phenology model (Busetto et al. 2010) was fit using nonlinear least squares regression to green leaf growth pattern over the growing season on every tiller in each year (for example fits see Fig. 1):

(1) $G(d)=\left[G_{\mathrm{Min}}+\left(G_{\mathrm{Max}}-G_{\mathrm{Min}}\right)\right]\left[\frac{1}{1+e^{-m S(d-S)}}+\frac{1}{1+e^{-m A(d-A)}}-1\right]$

where $G(t)$ is the green leaf length $(\mathrm{cm})$ at day of the year $(d), G_{\text {Max }}$ is the maximum green leaf length observed, $G_{\text {Min }}$ is the minimum green leaf length over the year (here set to $1 \mathrm{~cm}$ because E. vaginatum retains a small amount of green biomass over winter; Shaver and Laundre 1997), $m S$ is the spring growth rate, and $m A$ is the autumn senescence rate at time points $S$ and $A$, which are found halfway on the increase and decrease curves, respectively.

Phenology metrics specified by Busetto et al. (2010) as significant points on the phenology curve were extracted from each curve (Fig. 1). S1, S5, A1, and A5 are the time points at which changes in curvature are at their maximum or minimum (Busetto et al. 2010). S2, S4, A2, and A4 are dates at which the double logistic curve transitions from linear to nonlinear (or vice versa), and S3 and A3 are the points of maximum increase or decrease of the curve, respectively (Busetto et al. 2010). The tiller growing season (S1A1) was calculated as the number of days between metrics S1 and A1, which represents the period between the beginning of peak growth rate and the end of peak biomass (before senescence) and therefore when the majority of primary productivity takes place.

Poorly fitting models for individual tillers were removed from the dataset if they made biologically unrealistic estimates of spring (onset of growth (S1) before 1 April, growth rate $(m S)>0.4 \mathrm{~cm} \cdot \mathrm{day}^{-1}$ ) and peak growing season (S5A1) phenology (metric A1-S5 < 0). Additionally, if any phenology model had a particularly poor fit to the extent that it was an outlier compared with other fit models (root mean square error (RMSE) $>$ 95th percentile of all model fits), it was discarded. After this process, 130 curves from the three gardens could be analyzed in 2016 and 113 in 2017 (total of 20 removed). The curves were split 
relatively evenly between populations (SG, TL, or CF), sites (SG, TL, or CF) and treatments (OTC or control), resulting in even replication across all combinations (Supplementary Fig. $\left.S 1^{2}\right)$.

\section{Environmental data processing}

Air temperatures for Coldfoot and Sagwon were extracted and calculated from daily mean data from the SNOTEL database (http://www.wcc.nrcs.usda.gov/snow/) and from the Toolik Field Station Environmental Data Center of the University of Alaska, Fairbanks, Alaska, USA, for the Toolik Lake site. Snowmelt timing was extracted from the SNOWTEL database for Sagwon and Coldfoot and from the Environmental Data Center for the Toolik site (https://toolik.alaska.edu/edc/index.php). The end of the growing season was defined as the first day in autumn that the prior 7-day running mean minimum daily air temperature returned to $1^{\circ} \mathrm{C}$; consequently, the potential growing season length was determined as the number of days between snowmelt and a return to consistently low temperatures. We used a 7-day running mean temperature because cold snaps can happen at any time in the season, and we chose $1{ }^{\circ} \mathrm{C}$ because the 7-day running mean of $0{ }^{\circ} \mathrm{C}$ did not occur until long after all plant activity had ceased (October). Note that this was the authors' judgement of a "potential growing season length" for the purpose of this paper; to our knowledge, there is no recognized definition in this system. Late-season temperature was defined as the mean air temperature at each site between 1 and 14 August in any given year. This was deemed a period of time when plants are green but potentially receptive to phenological cues for senescence.

\section{Statistical analysis}

Linear mixed-effects models (Pinheiro et al. 2017) were used to test whether phenological variables (onset of growing season (S1), onset of senescence (A1), and growing season length (S1-A1)) were significantly affected by fixed effects - population source, common garden site, or sampling year - using the nlme package in $R$ ( $R$ Development Core Team 2016; Pinheiro et al. 2017). The tussock ID was used as a random intercept term. Models were simplified by removing interaction terms if they did not have a significant effect in order to get the best estimates of the main fixed effects (Crawley 2007). The effect of each factor in the final model was assessed relative to the null model (intercept only) by analysis of variance (ANOVA) (Crawley 2007). Linear mixed-effects models (tussock ID as random intercept term) were used to assess the effect of population and environmental factors: potential growing season length and the effect of snowmelt date and late-season temperature on the onset of growth, and onset of senescence, respectively. The number of days between the onset of growth and onset of senescence was used to determine actual growing season length. All analyses were carried out with $R$ version 3.3.3 ( $R$ Development Core Team 2016).

\section{Results}

Across all populations, tillers of E. vaginatum initiated growth earlier at Coldfoot than at the other two sites (Table 1; Fig. 2) but there was no significant difference between populations across all gardens $(P=0.195$, Table 1$)$. However, the $C F$ population responded to differences in site growing conditions more than the other populations, resulting in a significant interaction between populations and site (Table 1). The CF population started to senesce later than the northern ecotypes as represented by the TL and SG populations at all the sites (Fig. 2). But the onset of growth at Toolik Lake and Sagwon was significantly delayed after snowmelt in 2016, during which there were low temperatures in early June (Table 1; Supplementary Fig. $\mathrm{S}^{2}$ ). Thus, early June temperatures appeared to exert some control on the initiation of growth. 
Table 1. Test statistics from linear mixed-effects models showing the effect of fixed factors on growth patterns in Eriophorum vaginatum.

\begin{tabular}{|c|c|c|c|c|}
\hline Response variable & Fixed effect & df & $F$ & $P$ \\
\hline \multicolumn{5}{|c|}{ Nonwarmed transplanted tussocks } \\
\hline S1 (onset of growth) & $\begin{array}{l}\text { Population } \\
\text { Site } \\
\text { Year } \\
\text { Population } \times \text { site }\end{array}$ & $\begin{array}{l}2,81 \\
2,81 \\
1,57 \\
4,81\end{array}$ & $\begin{array}{r}1.7 \\
21.6 \\
7.0 \\
4.0\end{array}$ & $\begin{array}{r}0.195 \\
<0.001 \\
0.011 \\
0.005\end{array}$ \\
\hline A1 (onset of senescence) & $\begin{array}{l}\text { Population } \\
\text { Site } \\
\text { Year }\end{array}$ & $\begin{array}{l}2,85 \\
2,85 \\
1,57\end{array}$ & $\begin{array}{r}32.4 \\
3.4 \\
40.7\end{array}$ & $\begin{array}{r}<0.001 \\
0.038 \\
<0.001\end{array}$ \\
\hline S1A1 (growing season) & $\begin{array}{l}\text { Population } \\
\text { Site } \\
\text { Year } \\
\text { Population } \times \text { site }\end{array}$ & $\begin{array}{l}2,81 \\
2,81 \\
1,57 \\
4,81\end{array}$ & $\begin{array}{r}12.5 \\
13.1 \\
42.3 \\
3.7\end{array}$ & $\begin{array}{r}<0.001 \\
<0.001 \\
<0.001 \\
0.008\end{array}$ \\
\hline Maximum green length & $\begin{array}{l}\text { Population } \\
\text { Site } \\
\text { Year }\end{array}$ & $\begin{array}{l}2,87 \\
2,87 \\
1,68\end{array}$ & $\begin{array}{l}19.2 \\
10.1 \\
33.9\end{array}$ & $\begin{array}{l}<0.001 \\
<0.001 \\
<0.001\end{array}$ \\
\hline \multicolumn{5}{|c|}{ Warmed and nonwarmed transplant tussocks } \\
\hline A1 (onset of senescence) & $\begin{array}{l}\text { Population } \\
\text { Site } \\
\text { Year } \\
\text { Warming }\end{array}$ & $\begin{array}{l}2,112 \\
1,112 \\
1,79 \\
1,112\end{array}$ & $\begin{array}{r}18.4 \\
0.4 \\
58.4 \\
2.4\end{array}$ & $\begin{array}{r}<0.001 \\
0.552 \\
<0.001 \\
0.125\end{array}$ \\
\hline S1A1 (growing season) & $\begin{array}{l}\text { Population } \\
\text { Site } \\
\text { Year } \\
\text { Warming }\end{array}$ & $\begin{array}{l}2,112 \\
1,112 \\
1,79 \\
1,112\end{array}$ & $\begin{array}{r}10.6 \\
3.7 \\
38.3 \\
6.0\end{array}$ & $\begin{array}{r}<0.001 \\
0.056 \\
<0.001 \\
0.016\end{array}$ \\
\hline Maximum green length & $\begin{array}{l}\text { Population } \\
\text { Site } \\
\text { Year } \\
\text { Warming }\end{array}$ & $\begin{array}{l}2,115 \\
1,115 \\
1,91 \\
1,115\end{array}$ & $\begin{array}{r}13.4 \\
10.8 \\
38.3 \\
1.8\end{array}$ & $\begin{array}{r}<0.001 \\
0.001 \\
<0.001 \\
0.184\end{array}$ \\
\hline
\end{tabular}

Note: Data are divided into an analysis of transplant-only tussocks (no warming treatment, three common gardens) and an analysis that includes the effect of warming with open-top chambers (Sagwon and Toolik sites only). For model details see Supplementary Table $5^{2}$.

The southern ecotype had significantly longer leaves than did the northern ecotypes $(P<0.001$, Table 1$)$, although this difference was less pronounced at Toolik Lake than at the other two sites (Table 1; Supplementary Fig. S3 ${ }^{2}$ ). Warming with OTCs had no effect on leaf length (Table 1), but on average, over the 2 years, it did result in a significantly $(P<0.05)$ longer growing season, defined by the number of days between $S 1$ and A1 (Table 1; Fig. 2). Warming did not affect spring phenology or autumn phenology in a statistically detectable way, but the combined effects may have increased the overall season length slightly.

The effect of transplanting was analyzed by comparing tussocks that were transplanted into their "home" site with nontransplanted "control" tussocks. Across all sites, transplanting did not affect the onset of growth (metric S1; Supplementary Figs. S4 and S5 and Table $S 3^{2}$ ), but on average made the onset of senescence marginally earlier (metric A1, $P=0.066$; Supplementary Figs. S4 and S5 and Table $S 3^{2}$ ); however, this pattern was not consistent and depended on population. Growing season length was not affected by transplanting (metric S1A1; Supplementary Figs. S4 and S5 and Table S3 ${ }^{2}$ ), but transplanting did significantly reduce maximum green length compared with nontransplanted controls $\left(P=0.01\right.$; Supplementary Figs. S4 and S5 and Table S3 $\left.{ }^{2}\right)$. 
Fig. 2. Summary of growing season of Coldfoot (yellow), Toolik Lake (green), and Sagwon (blue) populations across all three common gardens and over 2 years. Points on the left signify mean \pm standard error (SE) onset of growing season (metric S1), and points on the right signify mean \pm SE onset of senescence (metric A1). The number of days between these (colored line) signifies the length of the growing season (metric A1S1). Statistics testing the effect of population, transplant garden (site), and year are found in Table 1; for model details see Supplementary Table $5^{2}$.
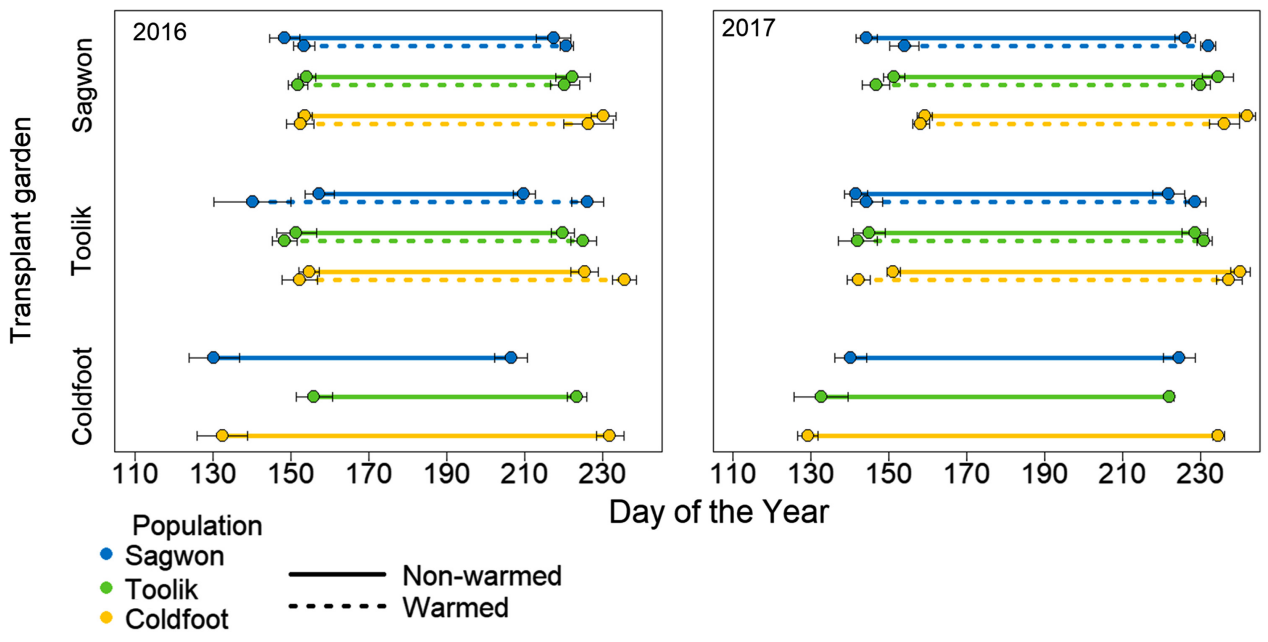

Coldfoot

There was no significant relationship between the date of growth onset and the date of senescence onset across populations and no interaction between onset of growth and population (Fig. 3; Supplementary Table $S 4^{2}$ ). CF populations consistently senesced later than the others, but this was unrelated to the onset of growth. Over the whole growing season, the actual growing season of leaves (metric S1A1) of all populations was positively affected by potential growing length, but the CF tussocks responded particularly strongly. This resulted in a statistically significant effect of potential growing season, population origin (CF was highest on average), and an interaction between the two (Fig. 4; Supplementary Table $S 4^{2}$ ). The onset of growth in spring was positively related to the day of snowmelt across all populations, but the CF population was particularly responsive, with initiation of growth closely tracking the loss of snow at any given site (Fig. 5; Supplementary Table $S 4^{2}$ ). In autumn, none of the populations in either year were responsive to differences in late-season environmental conditions (in this case, temperature in the first half of August). Instead, the populations maintained a significant difference in senescence timing regardless of the garden they were present in, with CF senescing particularly late (Fig. 6; Supplementary Table $\mathrm{S4}^{2}$ ). There were significant differences between years, with most tussocks senescing later in 2017 than in 2016.

\section{Discussion}

\section{Response of northern ecotypes to warming}

Climate change is progressing rapidly in Arctic ecosystems, and thus it is essential that tundra plants, which are adapted to cold environments, respond in kind. For the foundational species of moist acidic tundra, Eriophorum vaginatum, there is evidence that this long-lived species is already growing outside its optimal climate (McGraw et al. 2015). To better understand how this species will respond to climate change, we measured phenology and growth in reciprocal transplant experiments combined with warming using OTCs. First, we asked whether the phenology of the northern ecotypes can match longer growing 
Fig. 3. The day of onset of growth and the day of onset of senescence of leaves of Eriophorum vaginatum across all gardens populations in 2016 (squares) and 2017 (triangles). A linear mixed-effects model (Supplementary Table $\left.S 4^{2}\right)$ showed no effect of onset of growth on the onset of senescence $(P=0.388)$ but did show a significant effect of population $(P<0.001)$. Modelled marginal effects (with $95 \%$ confidence intervals) of onset of growth and population on the onset of senescence are displayed; for model details see Supplementary Table $S 5^{2}$.

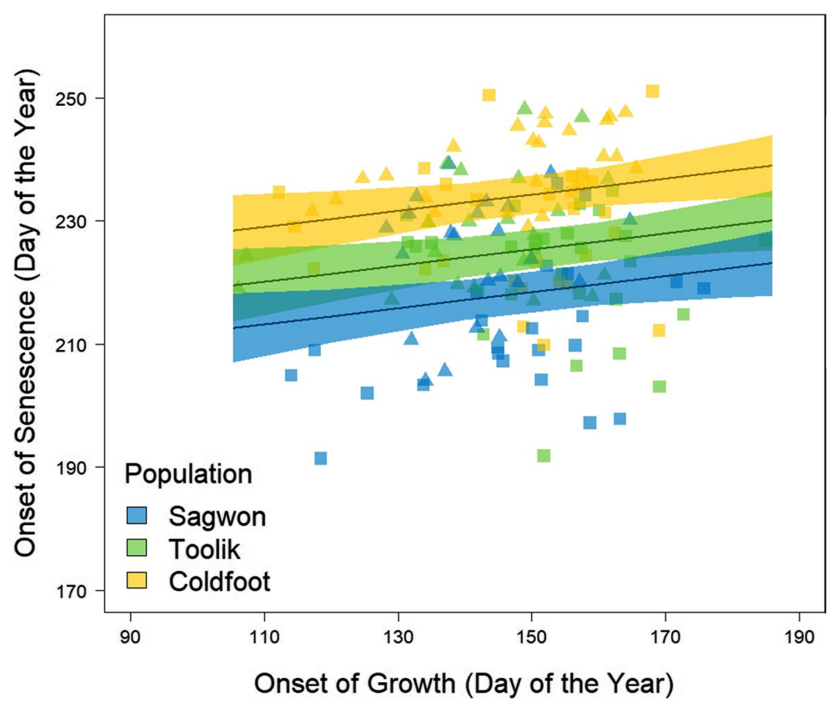

Fig. 4. Relationship between the potential growing season (snowmelt - return of cold temperatures) and the actual growing season (S1A1) for three populations in 2016 (squares) and 2017 (triangles). See Supplementary Table $S 4^{2}$ for linear mixed-effects models showing a significant effect of population $(P<0.001)$, a significant positive effect of potential growing season $(P<0.001)$, and significant interaction between the two $(P=0.002)$. Modelled marginal effects (with $95 \%$ confidence intervals) of potential growing season and population on actual growing season are displayed; for model details see Supplementary Table $\mathrm{S}^{2}$.

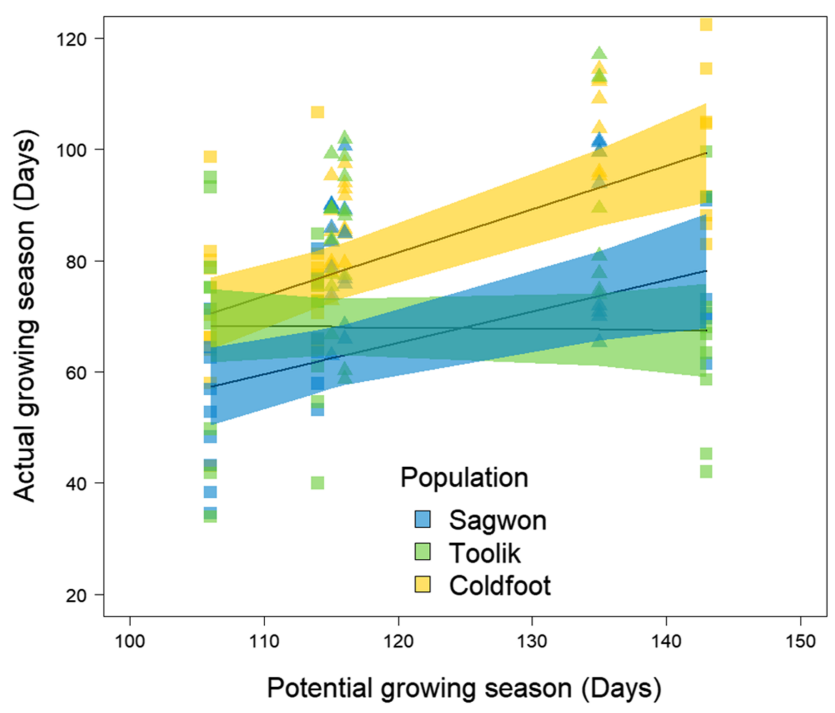

Published by Canadian Science Publishing 
Fig. 5. Relationship between snowmelt timing and onset of growth (S1) for three populations in 2016 (squares) and 2017 (triangles). See Supplementary Table $S 4^{2}$ for linear mixed-effects models showing no significant effect of population $(P=0.188)$, positive effect of snowmelt day $(P<0.001)$, and significant interaction between the two $(P<0.001)$. Modelled marginal effects (with $95 \%$ confidence intervals) of snowmelt day and population on the onset of growth are displayed; for model details see Supplementary Table $S 5^{2}$.

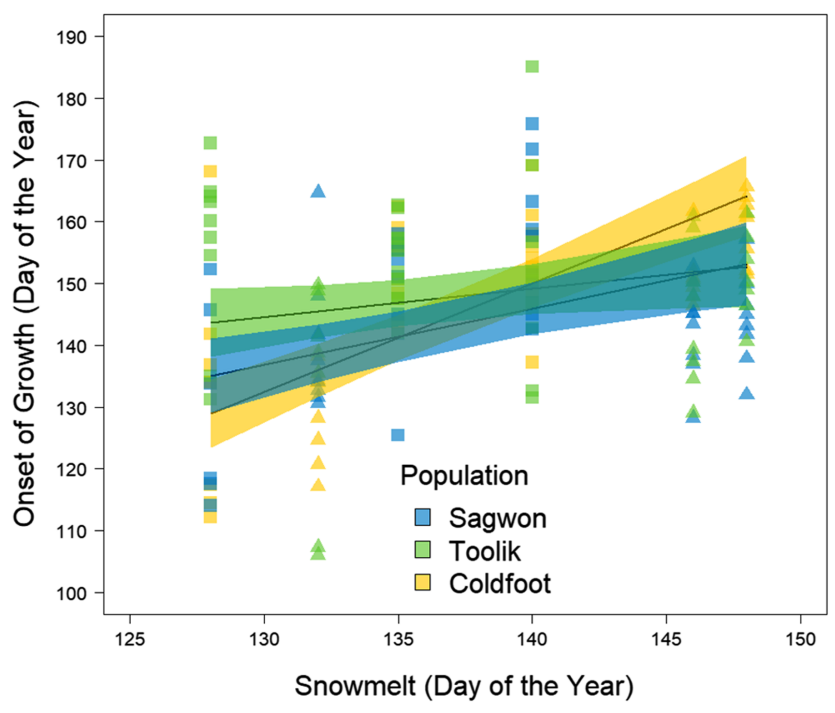

Fig. 6. Relationship between late-season temperature and onset of senescence (A1) for three populations in 2016 (squares) and 2017 (triangles). See Supplementary Table S4 ${ }^{2}$ for linear mixed-effects models showing a significant effect of population $(P<0.001)$ but no effect of late-season temperature $(P=0.575)$. Modelled marginal effects (with 95\% confidence intervals) of late-season temperature and population on the onset of senescence are displayed; for model details see Supplementary Table $5^{2}$.

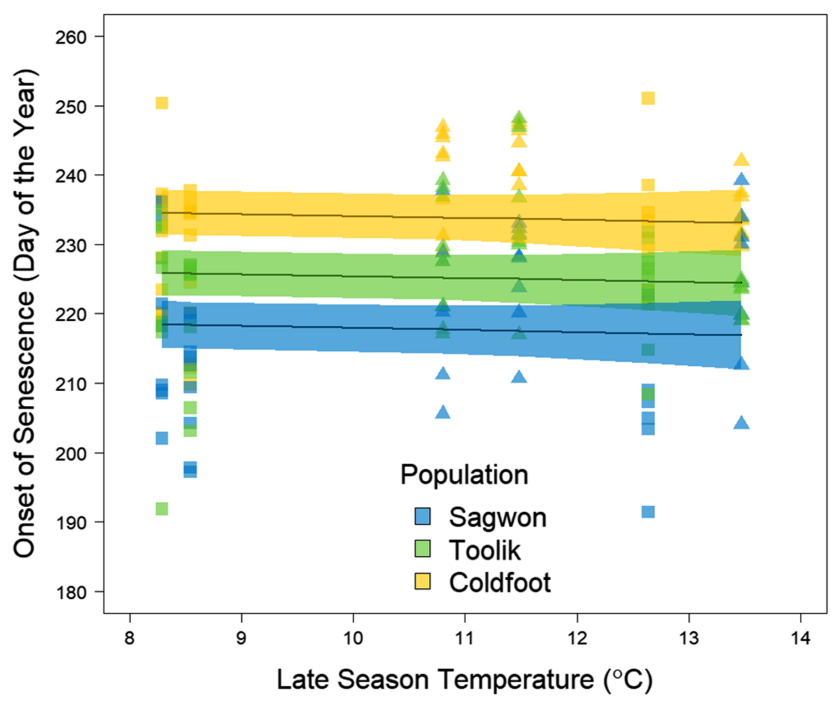

- Published by Canadian Science Publishing 
seasons when transplanted south. The Sagwon population did grow for longer when transplanted south to Coldfoot, managing to take advantage of earlier snowmelt followed by warm temperatures. Although the length of the growing season of the Toolik population did not change when the plants moved southward, the initiation of growth following snowmelt was earlier in 2017 compared with that at its home site. When the plants were experimentally warmed with OTCs, there was a general pattern across all populations of a slight increase in their growing season length, but the plants did not grow any larger. Taken together, the phenology of the northern ecotypes showed some responsiveness to climate change simulation, but the effects were mixed and relatively small. This is consistent with the lack of change in tiller size when northern populations from Sagwon, Toolik Lake, and Prudhoe Bay were moved south in an earlier experiment (Fetcher and Shaver 1990; Souther et al. 2014).

\section{Effects of transplanting on phenology of Eriophorum vaginatum}

By comparing the leaf growth phenology of tussocks transplanted into their "home" site with that of nontransplanted tussocks, we showed that there is a minimal effect of the physical disturbance on measured phenology traits (Supplementary Figs. S4 and $5^{2}$ ). This is an effect that is often assumed in such experiments (Parker et al. 2017; Walker et al. 2018; Curasi et al. 2019), but rarely tested. One of the advantages of E. vaginatum for reciprocal transplants is its deciduous root system and lack of mycorrhizal symbiosis, which means that tussocks can be transplanted without disturbing the belowground environment (Shaver et al. 1986; Parker et al. 2017; Schedlbauer et al. 2018). To this feature we can now add the relative lack of response of phenology to transplanting. The timing of the onset of growth and the length of the growing season were not different. The timing of senescence was overall marginally earlier, and the maximum length of leaves was slightly shorter, which perhaps reflects a less well-established connection between rhizomes and the soil, resulting in less effective nutrient uptake. These data further underline the usefulness of E. vaginatum as a model species to study ecotypic variation of traits in mature plants.

\section{Tussock competitiveness in a warming tundra}

Eriophorum vaginatum will need to contend with changing temperature regimes as well as increasing competition from plant functional types that respond well under warming. The Arctic is warming rapidly (Mudryk et al. 2019), and there is only limited evidence as to how well E. vaginatum will fare in these warmer conditions. Parker et al. (2017) were not able to detect a response to simulated warming, but Sullivan and Welker (2005) showed that warming to a level similar to that in our experiments initiated early-season growth of $E$. vaginatum in the tundra. Our study showed that tussocks across all populations stayed green for 3.76 days longer in response to direct warming, but little else was responsive. Therefore, it is not clear whether the response of E. vaginatum to a gradual temperature increase will have tangible ecosystem effects. OTC experiments have recently showed that tundra plant communities (including moist acidic tundra, dominated by E. vaginatum) extend their growing season when warmed (May et al. 2020). This suggests that contemporary plant communities can take advantage of milder growing conditions, at least in the short term. In the long term, however, the future success of E. vaginatum may depend more on the performance of its fellow community members than on its own performance. Plants in many areas of tundra are becoming more productive and taller in response to climate change (Bjorkman et al. 2018), and deciduous shrubs are often the plants that increase growth the most as the climate warms (Elmendorf et al. 2012a). If deciduous shrubs overgrow tussocks, which are more limited in their ability to grow taller, then the foundation species of moist acidic tundra may suffer declines. However, if tussocks remain green for 
longer in extended growing seasons (Park et al. 2016), and extend beyond that of shrubs, they may retain an important place in northern ecosystems. Eriophorum vaginatum remains photosynthetically active as long as it holds green leaves into August (Curasi et al. 2019); hence tussocks that can delay senescence may continue to accumulate carbon later into the season, after other species have dropped their leaves.

\section{Plasticity and competitiveness of southern ecotypes}

If the northern populations of E. vaginatum have only limited potential to respond to climate warming, can tussock tundra be maintained if southern populations or their genes move northward? In our study, the Coldfoot ecotype from the warmer site south of the treeline $(\mathrm{CF})$ did show plasticity in spring because the timing of green-up varied with the time of snowmelt. At the same time, senescence of the southern ecotype occurred later than that of the northern ecotypes across all environments, resulting in an apparent plasticity of growing season length in the CF ecotype. Using a single common garden in moist acidic tundra, Parker et al. (2017) showed that the southern ecotype grows later into the season and suggested that this trait is driven by adaptation to their warmer home site in the south. We show here that the southern ecotype maintains green leaves on average longer than the northern ecotypes (16 days longer than SG, and 9 days longer than TL), regardless of which common garden they are growing in (700 thawing degree days difference between CF and SG gardens). Green leaves in E. vaginatum retain active photosynthetic tissue late into August (Curasi et al. 2019); therefore, if southern ecotypes can migrate north in sync with climate warming, then they may increase the fitness of a species that is currently suffering in situ (McGraw et al. 2015). Southern ecotypes grow taller leaves (Fetcher and Shaver 1990) and maintain green tissue later in the season than northern ecotypes, therefore they may have a greater capacity for carbon fixation (Shaver et al. 1997). As southern ecotypes are dependent on dispersal by wind and suitable ecosystem disturbance for seedling establishment (McGraw et al. 2015), their northward migration could potentially have ecosystem-level impacts by influencing net ecosystem exchange. This needs to be tested by explicitly considering tussocks (transplanted and nontransplanted) in ecosystem analyses. Furthermore, studies that measure ecosystem processes are currently limited by peak-season-only measurements (Souther et al. 2014; Walker et al. 2018; Curasi et al. 2019); in order to integrate ecotypes into ecosystem gas exchange, the whole growing season needs to be considered.

The pattern of greater spring phenological plasticity in the southernmost E. vaginatum population stands in contrast to results from the community-wide large-scale synthesis of phenology (Prevéy et al. 2017). The results from this synthesis extended over $21^{\circ}$ of latitude and over $10^{\circ}$ further north than our most northern site (SG). At very high latitudes, in the harsh growing conditions of the High Arctic desert, the benefit of earlier spring green-up may outweigh the risk of damage by variation in early-season weather (cold snaps) (Prevéy et al. 2017); thus, more northern sites had higher plasticity. In the present experiment, the southern ecotypes showed more plasticity in the timing of green-up. At Coldfoot, there may be less environmental risk to greening-up as soon as the snow melts, whereas in the tundra there is a high risk that harsh growing conditions will return post snowmelt (Supplementary Table S2 ${ }^{2}$; Parker et al. 2017).

\section{Environmental versus genetic controls on phenology}

Because snowmelt in the tundra is getting earlier and causing earlier plant green-up (Park et al. 2016; Assmann et al. 2019), one of the next questions is how does this affect biological processes later in the growing season and how does this compare with other important controls on late-season phenology? Question 4 in our study arose from the 
hypothesis that some Arctic plant species are periodic (Semenchuk et al. 2016). Under this hypothesis, early green-up would result in early senescence due to genetic control over the length of E. vaginatum's growing season. We found no evidence to support this hypothesis. In contrast to the findings of other authors (Khorsand Rosa et al. 2015; Semenchuk et al. 2016), we found no relationship between timing of early-season and late-season phenology. Instead, we found that timing of senescence is best predicted by the population origin of the tussock. This is postulated to be the result of genetic adaptations to past environmental conditions, which genotype-environment association studies support as a driver in forming population structure conditions and patterns of E. vaginatum in northcentral Alaska (glaciation (E. Stunz, personal communication). Senescing at the right time is particularly important in the Arctic, where the abrupt start of winter can be harsh and damaging to exposed tissues (McGraw and et al. 1983). Therefore, it is plausible that genetic control over average timing of the return of cold temperatures at each of the home sites has a role in shaping the observed phenological patterns in the three populations studied.

While previous selection pressure clearly has a part to play in shaping contemporary late-season phenology, it is important to consider the plastic response of phenology to environmental factors. Cold snaps and frost can cause senescence in multiple species (McGraw et al. 1983), and a warm late season can delay senescence (May et al. 2017). We observed later senescence at the northern sites in 2017 than in 2016, when late-season temperatures were significantly warmer (Fig. 6), but more years of measurements at the same sites would be needed to start to determine the driving factors behind this variation. Temperatures towards the end of the growing season are quite variable, but photoperiod or the quality of light could be a more reliable cue for triggering senescence. The length of photoperiod was shown to be critical for growth cessation in Salix pentandra, with northern populations requiring a shorter dark period to stop growth (Junttila and Kaurin 1985). This is consistent with the need to cease growing before an early frost occurs, which is more likely at higher latitudes. Another potentially important but equally understudied light cue for senescence in Arctic plants is the ratio of red to far red light as monitored by the phytochrome photoreceptors (Buchanan et al. 2015). As discussed by Parker et al. (2017) research into the sensitivity of tundra plants to light quality should remain a priority for future research.

\section{Conclusions}

In the tundra ecosystem dominated by E. vaginatum, the growing season of the northern ecotypes had a limited response to longer, more favorable growing conditions when plants were transplanted south and therefore limited the potential to sequester carbon during the warm shoulder seasons. The Arctic is warming faster than any other biome on Earth (Park et al. 2018), and warming is particularly pronounced in the shoulder seasons, resulting in longer growing seasons (Park et al. 2016). Our results support the hypothesis that the southern ecotype of $E$. vaginatum is better adapted to take advantage of this warming through having more plasticity in its phenological response, but the northern ecotypes are more constrained and therefore would be unable to take advantage of a lengthened growing season (Fetcher and Shaver 1990). If plants in the Arctic continue to become more productive (Epstein et al. 2012) and grow taller (Bjorkman et al. 2018), then locally adapted ecotypes lacking the ability to extend growth in height or phenology in the northern part of their range, as we found for E. vaginatum, may need to rely on gene flow from southern populations to maintain a competitive balance in the ecosystem. At the present rate of climate change, the northern ecotypes already appear to be poorly adapted if the climate warms to the temperatures currently encountered by the southern ecotype (McGraw et al. 2015). Given the slow growth and longevity of tussock-forming plants in the Arctic, the 
chances for establishment of southern ecotypes in the north seem unlikely, outside of assisted gene flow or migration (Borrell et al. 2020).

\section{Acknowledgements}

Thanks to Alana Thurston, Darrell Dech, David Heinz, Elizabeth Fortin, Jon Gewirtzman, Myra Melendez, Sophia Iglesia, and Stephen Turner for field assistance and Gus Shaver for advice. We also appreciate the helpful comments from two anonymous reviewers.

\section{Competing interests}

The authors declare there are no competing interests.

\section{Contributors' statement}

N.F., M.L.M., J.T., and T.C.P. designed the experiment and measurement routine, and T.C.P., N.F., and S.U. took the measurements. All of the authors contributed to writing the manuscript.

\section{Funding}

Funding for this research was provided through the National Science Foundation (NSF/ PLR 1418010 to N.F., NSF/PLR 1417645 to M.L.M., and NSF/PLR 1417763 to J.T.). Logistic support came from Toolik Field Station and the Arctic Long-Term Ecological Research (LTER) (NSF/ PLR 1637459).

\section{Data availability statement}

Raw leaf length data that underpin the paper are supplied in the Supplementary Excel file $^{2}$.

\section{References}

Assmann, J.J., Myers-Smith, I.H., Phillimore, A.B., Bjorkman, A.D., Ennos, R.E., Prevéy, J.S., et al. 2019. Local snow melt and temperature - but not regional sea ice - explain variation in spring phenology in coastal Arctic tundra. Global Change Biol. 25: 2258-2274. doi: 10.1111/gcb.14639. PMID: 30963662.

Bennington, C.C., Fetcher, N., Vavrek, M.C., Shaver, G.R., Cummings, K.J., and McGraw, J.B. 2012. Home site advantage in two long-lived arctic plant species: results from two 30-year reciprocal transplant studies. J. Ecol. 100(4): 841-851. doi: 10.1111/j.1365-2745.2012.01984.x.

Bjorkman, A.D., Elmendorf, S.C., Beamish, A.L., Vellend, M., and Henry, G.H.R. 2015. Contrasting effects of warming and increased snowfall on Arctic tundra plant phenology over the past two decades. Global Change Biol. 21(12): 4651-4661. doi: 10.1111/gcb.13051. PMID: 26216538.

Bjorkman, A.D., Vellend, M., Frei, E.R., and Henry, G.H.R. 2017. Climate adaptation is not enough: warming does not facilitate success of southern tundra plant populations in the high Arctic. Global Change Biol. 23(4): 1540-1551. doi: 10.1111/gcb.13417. PMID: 27391174.

Bjorkman, A.D., Myers-Smith, I.H., Elmendorf, S.C., Normand, S., Rüger, N., Beck, P.S.A., et al. 2018. Plant functional trait change across a warming tundra biome. Nature, 562: 57-62. doi: 10.1038/s41586-018-0563-7. PMID: 3025822.

Borrell, J.S., Zohren, J., Nichols, R.A., and Buggs, R.J. 2020. Genomic assessment of local adaptation in dwarf birch to inform assisted gene flow. Evol. Appl. 13(1): 161-175. doi: 10.1111/eva.12883. PMID: 31892950.

Box, J.E., Colgan, W.T., Christensen, T.R., Schmidt, N.M., Lund, M., Parmentier, F.J.W., et al. 2019. Key indicators of Arctic climate change: 1971-2017. Environ. Res. Lett. 14: 45010. doi: 10.1088/1748-9326/aafc1b.

Brown, R., Schuler, D.V., Bulygina, O., Derksen, C., Luojus, K., Mudryk, L., et al. 2017. Arctic terrestrial snow cover. In Snow, Water, Ice and Permafrost in the Arctic (SWIPA) 2017. Arctic Monitoring and Assessment Programme (AMAP), Oslo, Norway. pp. 25-64.

Buchanan, B.B., Gruissem, W., and Jones, R.L. 2015. Biochemistry and molecular biology of plants. 2nd ed. John Wiley \& Sons, Hoboken, N.J., USA.

Busetto, L., Colombo, R., Migliavacca, M., Cremonese, E., Meroni, M., Galvagno, M., et al. 2010. Remote sensing of larch phenological cycle and analysis of relationships with climate in the Alpine region. Global Change Biol. 16(9): 2504-2517. doi: 10.1111/j.1365-2486.2010.02189.x.

Chapin, F.S., III, and Shaver, G.R. 1985. Individualistic growth response of tundra plant species to environmental manipulations in the field. Ecology, 66: 564-576. doi: 10.2307/1940405.

Chapin, F.S., III, Van Cleve, K., and Chapin, M.C. 1979. Soil temperature and nutrient cycling in the tussock growth form of Eriophorum vaginatum. J. Ecol. 67: 169-189. doi: 10.2307/2259343. 
Crawley, M.J. 2007. The R book. Wiley, Chichester, UK.

Curasi, S.R., Parker, T.C., Rocha, A.V., Moody, M.L., Tang, J., and Fetcher, N. 2019. Differential responses of ecotypes to climate in a ubiquitous Arctic sedge: implications for future ecosystem C cycling. New Phytol. 223(1): 180-192. doi: 10.1111/nph.15790.

Elmendorf, S.C., Henry, G.H.R., Hollister, R.D., Björk, R.G., Bjorkman, A.D., Callaghan, T.V, et al. 2012a. Global assessment of experimental climate warming on tundra vegetation: heterogeneity over space and time. Ecol. Lett. 15(2): 164-175. doi: 10.1111/j.1461-0248.2011.01716.x.

Elmendorf, S.C., Henry, G.H.R., Hollister, R.D., Bjork, R.G., Boulanger-Lapointe, N., Cooper, E.J., et al. $2012 b$. Plot-scale evidence of tundra vegetation change and links to recent summer warming. Nat. Clim. Change, 2: 453-457. doi: 10.1038/nclimate1465.

Epstein, H.E., Raynolds, M.K., Walker, D.A., Bhatt, U.S., Tucker, C.J., and Pinzon, J.E. 2012. Dynamics of aboveground phytomass of the circumpolar Arctic tundra during the past three decades. Environ. Res. Lett. 7(1): 015506. doi: 10.1088/1748-9326/7/1/015506.

Fetcher, N., and Shaver, G.R. 1982. Growth and tillering patterns within tussocks of Eriophorum vaginatum. Ecography, 5: 180-186. doi: 10.1111/j.1600-0587.1982.tb01034.x.

Fetcher, N., and Shaver, G.R. 1990. Environmental sensitivity of ecotypes as a potential influence on primary productivity. Am. Nat. 136: 126-131. doi: 10.1086/285085.

Hamilton, T.D. 2003. Glacial geology of the Toolik Lake and upper Kuparuk River regions. University of Alaska, Institute of Arctic Biology. Available from https://scholarworks.alaska.edu/bitstream/11122/1502/1/BiologicalPapers_ no26.pdf.

Hereford, J. 2009. A quantitative survey of local adaptation and fitness trade-offs. Am. Nat. 173(5): 579-588. doi: $10.1086 / 597611$.

Høye, T.T., Post, E., Meltofte, H., Schmidt, N.M., and Forchhammer, M.C. 2007. Rapid advancement of spring in the High Arctic. Curr. Biol. 17(12): R449-R451. doi: 10.1016/j.cub.2007.04.047. PMID: 17580070.

Junttila, O., and Kaurin, Å. 1985. Climatic control of apical growth cessation in latitudinal ecotypes of Salix pentandra L. In Plant Production in the North: Proceedings from Plant Adaptation Workshop, Tromso, Norway, 4-9 September 1983. Edited by A. Kaurin, O. Juntilla, and J. Nilsen. pp. 85-91.

Kaufman, D.S., and Manley, W.F. 2004. Pleistocene maximum and Late Wisconsinan glacier extents across Alaska, USA. Dev. Quat. Sci. 2: 9-27.

Kaufman, D.S., Young, N.E., Briner, J.P., and Manley, W.F. 2011. Alaska Palaeo-glacier atlas (version 2). In Quaternary glaciations - extent and chronology, Part IV: a closer look. Developments in Quaternary Science. Edited by J. Ehlers, P.L. Gibbard, and P. Hughes. Elsevier. Vol. 15, pp. 427-445.

Khorsand Rosa, R., Oberbauer, S.F., Starr, G., Parker La Puma, I., Pop, E., Ahlquist, L., and Baldwin, T. 2015. Plant phenological responses to a long-term experimental extension of growing season and soil warming in the tussock tundra of Alaska. Global Change Biol. 21(12): 4520-4532. doi: 10.1111/gcb.13040. PMID: 26183112.

Leimu, R., and Fischer, M. 2008. A meta-analysis of local adaptation in plants. PLoS ONE, 3(12): e4010. doi: 10.1371/ journal.pone.0004010. PMID: 19104660.

Linhart, Y.B., and Grant, M.C. 1996. Evolutionary significance of local genetic differentiation in plants. Annu. Rev. Ecol. Syst. 27: 237-277. doi: 10.1146/annurev.ecolsys.27.1.237.

Mark, A.F., Fetcher, N., Shaver, G.R., and Chapin, F.S., III. 1985. Estimated ages of mature tussocks of Eriophorum vaginatum along a latitudinal gradient in central Alaska, U.S.A. Arct. Alp. Res. 17: 1-5. doi: 10.2307/1550957.

May, J.L., Healey, N.C., Ahrends, H.E., Hollister, R.D., Tweedie, C.E., Welker, J.M., et al. 2017. Short-term impacts of the air temperature on greening and senescence in Alaskan Arctic plant tundra habitats. Remote Sens. 9(12): 1338. doi: $10.3390 /$ rs9121338.

May, J.L., Hollister, R.D., Betway, K.R., Harris, J.A., Tweedie, C.E., Welker, J.M., et al. 2020. NDVI changes show warming increases the length of the green season at tundra communities in northern Alaska: a fine-scale analysis. Front. Plant Sci. 11: 1174. doi: 10.3389/fpls.2020.01174. PMID: 32849728.

McGraw, J.B., Chester, A.L., and Stuart, L. 1983. A note on July senescence in tundra plants at Eagle Creek, Alaska, USA. Arct. Alp. Res. 15: 267-269. doi: 10.2307/1550928.

McGraw, J.B., Turner, J.B., Souther, S., Bennington, C.C., Vavrek, M.C., Shaver, G.R., and Fetcher, N. 2015. Northward displacement of optimal climate conditions for ecotypes of Eriophorum vaginatum L. across a latitudinal gradient in Alaska. Global Change Biol. 21(10): 3827-3835. doi: 10.1111/gcb.12991. PMID: 26033529.

Mohl, J.E., Fetcher, N., Stunz, E., Tang, J., and Moody, M.L. 2020. Comparative transcriptomics of an arctic foundation species, tussock cottongrass (Eriophorum vaginatum), during an extreme heat event. Sci. Rep. 10: 8990. doi: 10.1038/s41598-020-65693-8. PMID: 32488082.

Mudryk, L., Brown, R., Luojus, K., Decharme, B., and Helfrich, S. 2019. Terrestrial snow cover. In Arctic Report Card 2019. Available from http://www.arctic.noaa.gov/Report-Card.

Myers-Smith, I.H., Forbes, B.C., Wilmking, M., Hallinger, M., Lantz, T., Blok, D., et al. 2011. Shrub expansion in tundra ecosystems: dynamics, impacts and research priorities. Environ. Res. Lett. 6: 045509. doi: 10.1088/1748-9326/6/ $4 / 045509$.

Myers-Smith, I.H., Thomas, H.J.D., and Bjorkman, A.D. 2019. Plant traits inform predictions of tundra responses to global change. New Phytol. 221: 1742-1748. doi: 10.1111/nph.15592. PMID: 30444539.

Oberbauer, S.F., Elmendorf, S.C., Troxler, T.G., Hollister, R.D., Rocha, A.V., Bret-Harte, M.S., et al. 2013. Phenological response of tundra plants to background climate variation tested using the International Tundra Experiment. Philos. Trans. R. Soc., B: Biol. Sci. 368(1624): 20120481. doi: 10.1098/rstb.2012.0481. PMID: 23836787. 
Park, K., Kang, S.M., Kim, D., Stuecker, M.F., and Jin, F.-F. 2018. Contrasting local and remote impacts of surface heating on polar warming and amplification. J. Clim. 31(8): 3155-3166. doi: 10.1175/JCLI-D-17-0600.1.

Park, T., Ganguly, S., Tømmervik, H., Euskirchen, E.S., Høgda, K.-A., Karlsen, S.R., et al. 2016. Changes in growing season duration and productivity of northern vegetation inferred from long-term remote sensing data. Environ. Res. Lett. 11: 084001. doi: 10.1088/1748-9326/11/8/084001.

Parker, T.C., Tang, J., Clark, M.B., Moody, M.M., and Fetcher, N. 2017. Ecotypic differences in the phenology of the tundra species Eriophorum vaginatum reflect sites of origin. Ecol. Evol. 7(22): 9775-9786. doi: 10.1002/ece3.3445. PMID: 29188008.

Pinheiro, J., Bates, D., DebRoy, S., Sarkar, D., and R Core Team. 2017. nlme: linear and nonlinear mixed effects models. R-Project. Available from https://cran.r-project.org/package=nlme.

Post, E., Forchhammer, M.C., Bret-Harte, M.S., Callaghan, T.V, Christensen, T.R., Elberling, B., et al. 2009. Ecological dynamics across the Arctic associated with recent climate change. Science, 325: 1355-1358. doi: 10.1126/ science.1173113. PMID: 19745143.

Prevéy, J., Vellend, M., Rüger, N., Hollister, R.D., Bjorkman, A.D., Myers-Smith, I.H., et al. 2017. Greater temperature sensitivity of plant phenology at colder sites: implications for convergence across northern latitudes. Global Change Biol. 23: 2660-2671. doi: 10.1111/gcb.13619. PMID: 28079308.

R Development Core Team. 2016. R: a language and environment for statistical computing. R Foundation for Statistical Computing, Vienna, Austria. Available from https://www.r-project.org.

Schedlbauer, J.L., Fetcher, N., Hood, K., Moody, M.L., and Tang, J. 2018. Effect of growth temperature on photosynthetic capacity and respiration in three ecotypes of Eriophorum vaginatum. Ecol. Evol. 8(7): 3711-3725. doi: 10.1002/ece3.3939. PMID: 29686852.

Semenchuk, P.R., Gillespie, M.A.K., Rumpf, S.B., Baggesen, N., Elberling, B., and Cooper, E.J. 2016. High Arctic plant phenology is determined by snowmelt patterns but duration of phenological periods is fixed: an example of periodicity. Environ. Res. Lett. 11(12): 125006. doi: 10.1088/1748-9326/11/12/125006.

Shaver, G.R., and Laundre, J.1997. Exsertion, elongation, and senescence of leaves of Eriophorum vaginatum and Carex bigelowii in Northern Alaska. Global Change Biol. 3: 146-157. doi: 10.1111/j.1365-2486.1997.gcb141.x.

Shaver, G.R., Fetcher, N., and Chapin, F.S., III. 1986. Growth and flowering in Eriophorum vaginatum: annual and latitudinal variation. Ecology, 67(6): 1524-1535. doi: 10.2307/1939083.

Souther, S., Fetcher, N., Fowler, Z., Shaver, R.G., and McGraw, J.B. 2014. Ecotypic differentiation in photosynthesis and growth of Eriophorum vaginatum along a latitudinal gradient in the Arctic tundra. Botany, 92(8): 551-561. doi: $10.1139 / c j b-2013-0320$.

Sullivan, P.F., and Welker, J.M. 2005. Warming chambers stimulate early season growth of an arctic sedge: results of a minirhizotron field study. Oecologia, 142: 616-626. doi: 10.1007/s00442-004-1764-3. PMID: 15688218.

Wagner, I., and Simons, A.M. 2009. Divergence among arctic and alpine populations of the annual, Koenigia islandica: morphology, life-history, and phenology. Ecography, 32(1): 114-122. doi: 10.1111/j.1600-0587.2008.05497.x.

Walker, D.A., Raynolds, M.K., Daniëls, F.J.A., Einarsson, E., Elvebakk, A., Gould, W.A., et al. 2005. The circumpolar Arctic vegetation map. J. Veg. Sci. 16: 267-282. doi: 10.1111/j.1654-1103.2005.tb02365.x.

Walker, T.W.N., Weckwerth, W., Bragazza, L., Fragner, L., Forde, B.G., Ostle, N.J., et al. 2018. Plastic and genetic responses of a common sedge to warming have contrasting effects on carbon cycle processes. Ecol. Lett. 22: 159-169. doi: 10.1111/ele.13178. PMID: 30556313.

Wein, R.W. 1973. Biological flora of British-Isles — Eriophorum vaginatum L. J. Ecol. 61: 601-615. doi: 10.2307/2259047.

Wookey, P.A., Aerts, R., Bardgett, R.D., Baptist, F., Bråthen, K., Cornelissen, J.H.C., et al. 2009. Ecosystem feedbacks and cascade processes: understanding their role in the responses of Arctic and alpine ecosystems to environmental change. Global Change Biol. 15: 1153-1172. doi: 10.1111/j.1365-2486.2008.01801.x. 